\title{
All at Sea: Romanticism in Géricault's Raft of the Medusa
}

\author{
Galven Keng Yue Lee
}

All at sea. We - receptacles, tentacles

of ingestion and

Assemblage. A mass of ever-dying, ever-living

Vapid waves. All at sea.

$\sim$ Galven Keng Yue Lee

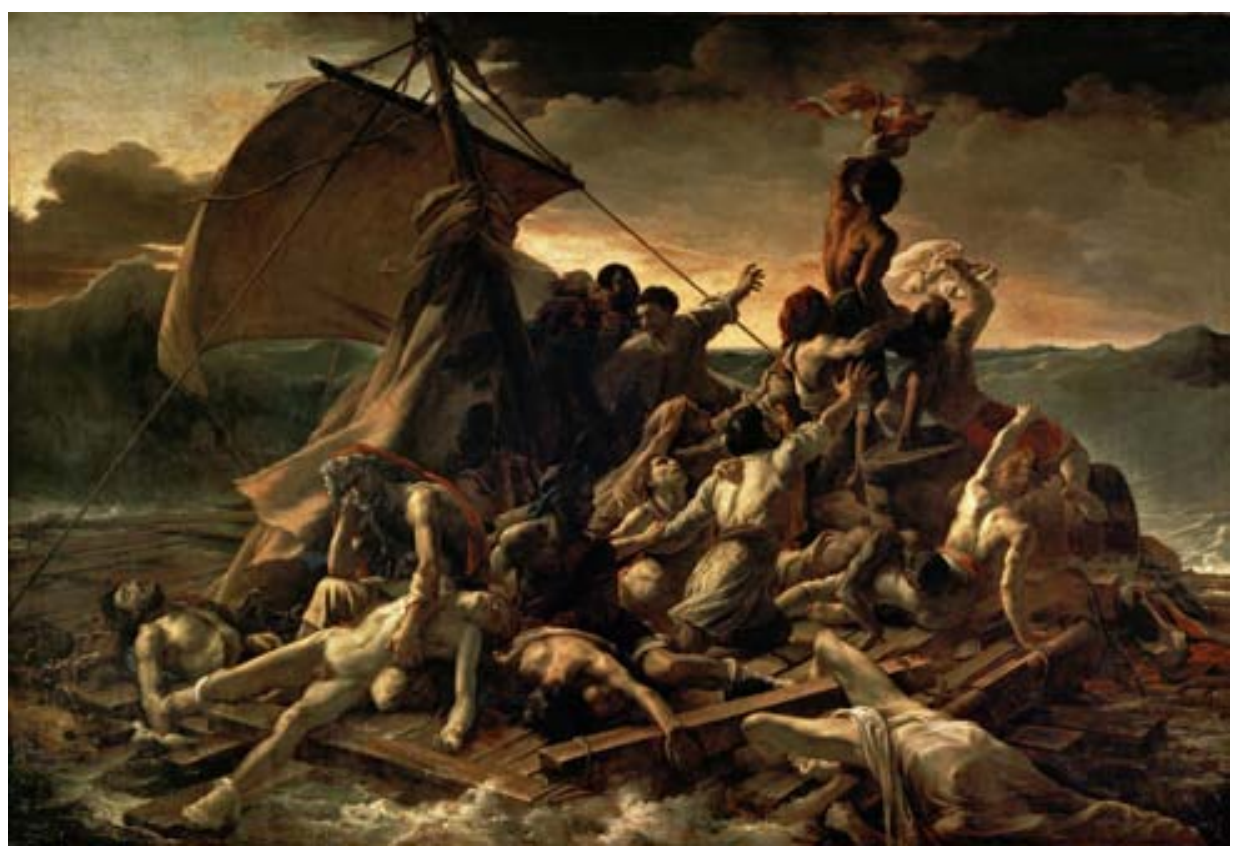

Plate 1: Théodore Géricault, Raft of the Medusa, 1819, oil on canvas, $491 \times 716 \mathrm{~cm}$.

Source: Musée du Louvre, Paris. Fair use is claimed for not-for-profit educational \& scholarship purposes.

\section{Abstract}

Théodore Géricault's painting, Raft of the Medusa, has long been regarded as a quintessentially Romantic painting. Yet it was unprecedented when it was exhibited at the 1819 Salon by its raw and direct appeal to the viewer's 
emotions, and represented an early stage in French Romantic painting. In this paper, I argue that the painting was an original, logical outcome of the social and political turbulence that plagued French society in the early nineteenth century and which also impinged itself on the personal circumstances of Géricault's life. It is through this general malaise and sense of crisis that the painting can not only be seen as an authentic product of its time, but also one that reflected the distinctly personal nature of the Romantic painting, through the intense personal involvement and identification of Géricault with its creation and subsequent legacy.

\section{Romanticism in Géricault's Raft of the Medusa}

Théodore Géricault's Raft of the Medusa is a stunning piece that strikes the viewer with its intense, emotional representations of hope and hopelessness. The pointless suffering of the denizens of the raft eradicate any pretensions to heroic achievement or tragic sacrifice; only the surging waves of the ocean respond without sympathy to their cries for salvation from a suffering which has only brought them to the pits of unheroic despair-drawing us within the vacant expression of the older man in the left foreground clutching onto the limp body of a younger male, possibly his son.

Unveiled at the Salon of 1819, when Géricault was 28 years old, it drew on and responded to the turbulent politics of the nascent Restoration regime of Louis XVIII. ${ }^{1}$ The portrayal of a vividly contemporary topic - the unfortunate incident of the sinking of the government frigate, La Méduse (The Medusa) along with the attendant stories of carnage, cannibalism, mutiny and murder, which had scandalised the French public and embarrassed the Restoration government - especially one without celebrated heroes, didactic value or any attempts to narrativise its subjects as worthy of cathartic salvation after their travails at sea, appeared unseemly for a large $(491$ by $716 \mathrm{~cm})$ history painting. ${ }^{2}$ Its carefully worded alternate title, Scene of Shipwreck, barely concealed its reference to the disaster that occurred just three years before. The French public had been informed about the torturous ordeal of the 150 people aboard a raft that was abandoned by the ship's lifeboats, through the politicised invective of an eyewitness account written by the ship's surgeon, Henri Savigny, and

\footnotetext{
1 The Salon was the official art exhibition of the Académie des Beaux-Arts, and was sanctioned by both the Bonapartist and Bourbon regimes. It was held biannually, and held in high esteem in the Western world. The Restoration regime of the Bourbon monarch, Louis XVIII, was so-called because it represented the restoration of the monarchy in 1814. This followed the tumultuous years of the French Revolution in 1789-99, and Napoléon Bonaparte's subsequent rise to power as First Consul, then as Emperor of the French from 1799 to 1814; Lorenz Eitner, Gericault's Raft of the Medusa (London: Phaidon, 1972), 1, 5-6.

2 See Appendix A for Eitner's narration of the Medusa debacle.
} 
the engineer-geographer, Alexandre Corréard, which was intensely critical of both the ship's captain as well as the favouritism and corruption in the royal administration that precipitated his appointment. ${ }^{3}$

But while Géricault was well aware of the politically sensitive nature of his subject matter, the figures in the painting are not portrayed to be the tragic heroes necessary to indict and demonise the regime for its failure. On the contrary, their complexions seem drained of warm hues and blend into the overwhelming, lustreless greys of the surging waves and overcast sky, evoking an implacable sense of death and decay. The focus on the human dimension of this tragedy can perhaps be read as implicit rebellion against the polemical debates and grand political themes that dominated much of the popular and artistic discourse of the day. Indeed, Géricault had observed that his friend Horace Vernet's success as a painter stemmed from his choice of modern subject matter. ${ }^{4}$ Artists were also very much dependent on official patronage to finance their career; even the previously loyal Bonapartist, Baron Gros, was forced to exhibit the Embarkation of the Duchess of Angouleme at the 1819 Salon, which commemorated the princess' resistance against the Bonapartists at Bourdeaux during the Hundred Days. ${ }^{5}$ In painting the Raft of the Medusa, Géricault acknowledged the pressures upon the artist to depict vital, modern and politically significant subjects, but subverted these constraints by painting a strikingly original scene that appealed directly to the viewer's emotions and not through familiar guides to comprehension. ${ }^{6}$

This Géricault was able to do with creative abandon because of inherited wealth. He was one of several nineteenth century painters, including Eugène Delacroix and Gustave Courbet, without formal training in the academy. ${ }^{7}$ He could thus improvise from and synthesise various artistic inclinations and styles during a period of self-directed artistic development that coincided with the turbulent politics of his era. His was a generation that would have heard and witnessed the swift rise to power and expansion of the Post-revolutionary French Empire during his youth, only to see the entire edifice crumble during early adulthood with the restoration of the Bourbon monarchy, shattering the illusion of imperial military glory which they had grown up with. ${ }^{8}$ The brief return of Napoléon to power during the Hundred Days, though to no eventual avail, would have further deepened a sense of restlessness and weary disillusionment with the swiftly changing tides of history. In this post-Enlightenment world, the focus

3 Nina Athanassoglou-Kallmyer, Théodore Géricault (London: Phaidon, 2010), 122-23.

4 Ibid., 18.

5 The Hundred Days refers to the period after Napoléon escaped from exile to seize power once again as emperor. He was finally defeated at the Battle of Waterloo and lived in exile till his death; Frank Anderson

Trapp, review of Géricault's Raft of the Medusa by Lorenz Eitner, The Art Bulletin 58, no. 1 (1976): 134.

6 Ibid., 42.

7 Trapp, review of Géricault's Raft, 136.

8 Athanassoglou-Kallmyer, Théodore Géricault, 26. 
was shifting towards the subjective constructs of humanity, into the realm of personality, emotions and introspection, building on the humanistic base provided by the Enlightenment.

The industrialising, democratising forces that were both cause and outcome of the egalitarian and modernist ideas of the Revolution were themselves responsible for an artist like Géricault's emergence. He was born into a wealthy bourgeois family, representative of a new elite that had consolidated its power and status under the Empire. ${ }^{9}$ This rising middle-class would not tolerate the unqualified hegemony of the aristocracy, but neither was it virulently anti-establishment. It was this tension between old world privilege and revolutionary modernity that Géricault inhabited. His wealth offered him the financial freedom to develop his artistic pursuits and pursue his passions for sportsmanship and horses unhindered. ${ }^{10}$ But he was also simultaneously plunged, in the year prior to beginning his work on the painting, into the midst of a rambunctious, proBonapartist bourgeois community at Montmartre, where he lived at his father's house. The central gathering place would be at the studio of Vernet. ${ }^{11}$ Their conversations must have revolved around the latest political and social events, plunging Géricault into an artistic setting that was consistently engaged with society. This tension between the old and new extended further to his artistic style, which sought to reconcile his appreciation of the grand, monumental Neoclassicist style of Jacques-Louis David with his passion for virile, fluid subjects. In negotiating between tradition and modernity, Géricault was one of the first artists of the nascent Romantic period to marshal these styles to suit the personal, human focus of the painting - a direction that was plausible for a comfortable middle-class gentleman in the stimulating and innovative intellectual climate of the Restoration.

This direction was made probable by the stormy circumstances of his private life in the years before the creation of the painting. Géricault had left for Italy in September 1816, intending to spend two years studying the monumental paintings of the Italian masters, but also to escape the sorrows of his forbidden, incestuous relationship with the young wife of his maternal uncle; he returned to Paris just one year later, driven back by loneliness and depression, eventually being forced to resolve his affair quietly after the birth of his illegitimate son in August 1818. ${ }^{12}$ The emotional toll that these events took on him was likely exacerbated by Géricault's virile and flighty personality, easily given to engage in fights and thriving on intense experiences. ${ }^{13}$ Starting work on the painting in autumn of that year, he lived in seclusion for eighteen months, in a period

9 Ibid., 8, 10.

10 Ibid., 15.

11 Eitner, Géricault's Raft, 13-14.

12 Ibid., 12-13.

13 Athanassoglou-Kallmyer, Théodore Géricault, 15. 
of relentless fascination and obsession with death- he collected cadavers and body parts, visited hospitals and beaches, enlisted the Medusa's carpenter to build a scale model of the raft, and made numerous sketches, drawings and even paintings of different sections of the narrative. ${ }^{14}$ The tumult in the public sphere was mirrored by the despair of his private life, generating subterranean currents that would create the impetus that drove him indefatigably towards the horrific and macabre. In fact, the subject of the Medusa was arrived at after abandoning an initial project about the murder of Antoine-Bernardin Fualdès, a former Jacobin who was allegedly murdered by right-wing, royalist extremists. ${ }^{15}$ Evidently, Géricault was becoming preoccupied with expressing an artistic vision that revealed the haunting contours of his imagination, an unfettered look within the nature of humanity, one he was free to explore as an artist not beholden or accountable to his patrons.

The forces impinging upon Géricault that pushed him in such a direction were by no means unique to him. Yet it is the intriguing and highly personal manner in which he was urged by the circumstances of the public and private spheres to create a painting that provides a rich insight into the emergence of Romanticism as an early response to those tumultuous times. It was also a protest against the failure of rationalism and the bankruptcy of appeals to grand concepts such as 'Empire' or 'Nation' to deliver stability and peace. As the French poet and critic Charles Baudelaire noted in 1846, at the tail end of the Romantic movement: "Romanticism is precisely situated neither in choice of subjects nor in exact truth, but in a way of feeling." ${ }^{16}$ In contrast with more uniform styles like the Baroque, supported by the Church and containing more distinctive subject matter, the Romantic eludes programmatic definition because it comprised a diverse reaction against prevailing styles. ${ }^{17}$ The fluid, asymmetrical motion of the figures in the painting and the realist depiction of raw emotion lie in stark contrast to the restrained forms and inner rationality of Neoclassical archetypes like David's Oath of the Horatii. In its retreat towards the inner world of emotion, Romanticism could only serve to reinforce the personality of the artist himself as being central to the creation of his art - not only was the Romantic painting the product of its times, it was these trying times that became the implicit subject of, and were given their fullest expression on, the canvas. By the time it was due for exhibition at the 1819 Salon, Géricault had evidently exhausted himself

\footnotetext{
14 Eitner, Géricault's Raft, 22-23.

15 The Jacobin club was the most radical French political club during the Revolution and was responsible for implementing the Reign of Terror, when thousands of people branded as 'enemies of the Revolution' were executed. Fualdès had also allegedly voted for the execution of Louis XVI. His murder coincided with the White Terror, when royalist gangs swept through France to purge their political opponents between 1816 and 1817. Suspicion of official involvement lingered even though the case was eventually attributed to simple robbery; Athanassoglou-Kallmyer, Théodore Géricault, 119, 122.

16 David Blayney Brown, Romanticism (London: Phaidon, 2001), 8.

17 Ibid.
} 
through the long hours and depressing themes that infested his art. He left for the country to rest, but his physical and mental condition soon deteriorated to the point where his friends brought him back to Paris to seek medical help. ${ }^{18}$ The Romantic artist, fixated on the subjective realms of individual experience and emotion, and who embraced the complexities of life in its phenomenological reality, soon became indistinguishable from his art.

Such conventions of the Romantic can only be observed with hindsight. Géricault did not set out to create a Romantic painting. His coming of age in the 1810s was a period where the Neoclassical style of David was getting tiresome, lacking the genuine conviction of public duty and patriotism that had marked its origins in the last quarter of the previous century. ${ }^{19}$ Napoléon had officially intervened to introduce a new category of history painting that depicted modern scenes with militaristic themes. ${ }^{20}$ Géricault must have been inspired by these monumental paintings of contemporary glory to paint the Portrait of anOfficer of the Chasseurs Commanding a Charge, which was well received at the 1812 Salon (Plate 2).

His ambition was "to shine, to illuminate, to astonish the world", and he had succeeded in combining two seemingly contrary instincts that had been with him from his early development - a tendency towards vitality and realism, and the grandeur of colossal images. ${ }^{21}$ But his next Salon painting, Wounded Cuirassier Leaving the Field, demonstrated the limitations of this realism in sustaining monumentality (Plate 3).

Disappointed, Géricault turned to the formal, controlled style of Neoclassicism, expressing his individuality by exuding an intensity that was more reminiscent of Michelangelo than David. ${ }^{22}$ This style he refined in Italy, reflecting once again his tendency towards the contemporary and realist, channelled with greater control and monumentality with its grand classicism, in The Race of the Riderless Horses (Plate 4). ${ }^{23}$

18 Eitner, Géricault's Raft, 57.

19 Lorenz E.A. Eitner and Steven A. Nash, Gericault: 1791-1824 (San Francisco: The Fine Arts Museums of San Francisco, 1989), 16.

20 Ibid.

21 From a manuscript by Géricault, quoted in Charles Clément, Géricault, etude biographique et critique (Paris, 1867), 249, quoted in Eitner, Raft, 15.

22 Eitner, Géricault's Raft, 16.

23 Géricault made several studies for this project, but failed to complete it. 


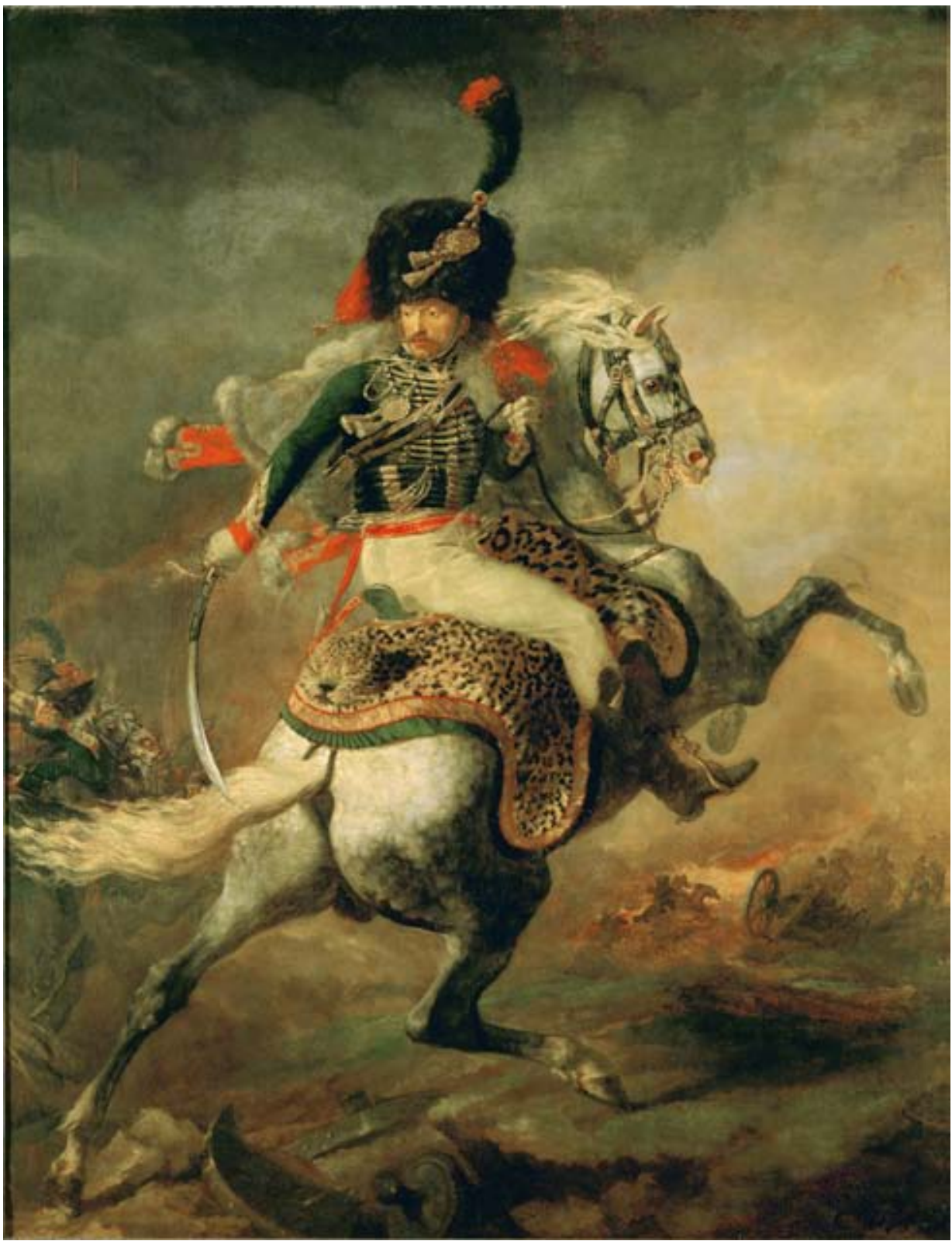

Plate 2: Théodore Géricault, Portrait of an Officer of the Chasseurs Commanding a Charge, 1812, oil on canvas, 349 x $266 \mathrm{~cm}$.

Source: Musée du Louvre, Paris. Fair use is claimed for not-for-profit educational \& scholarship purposes. 


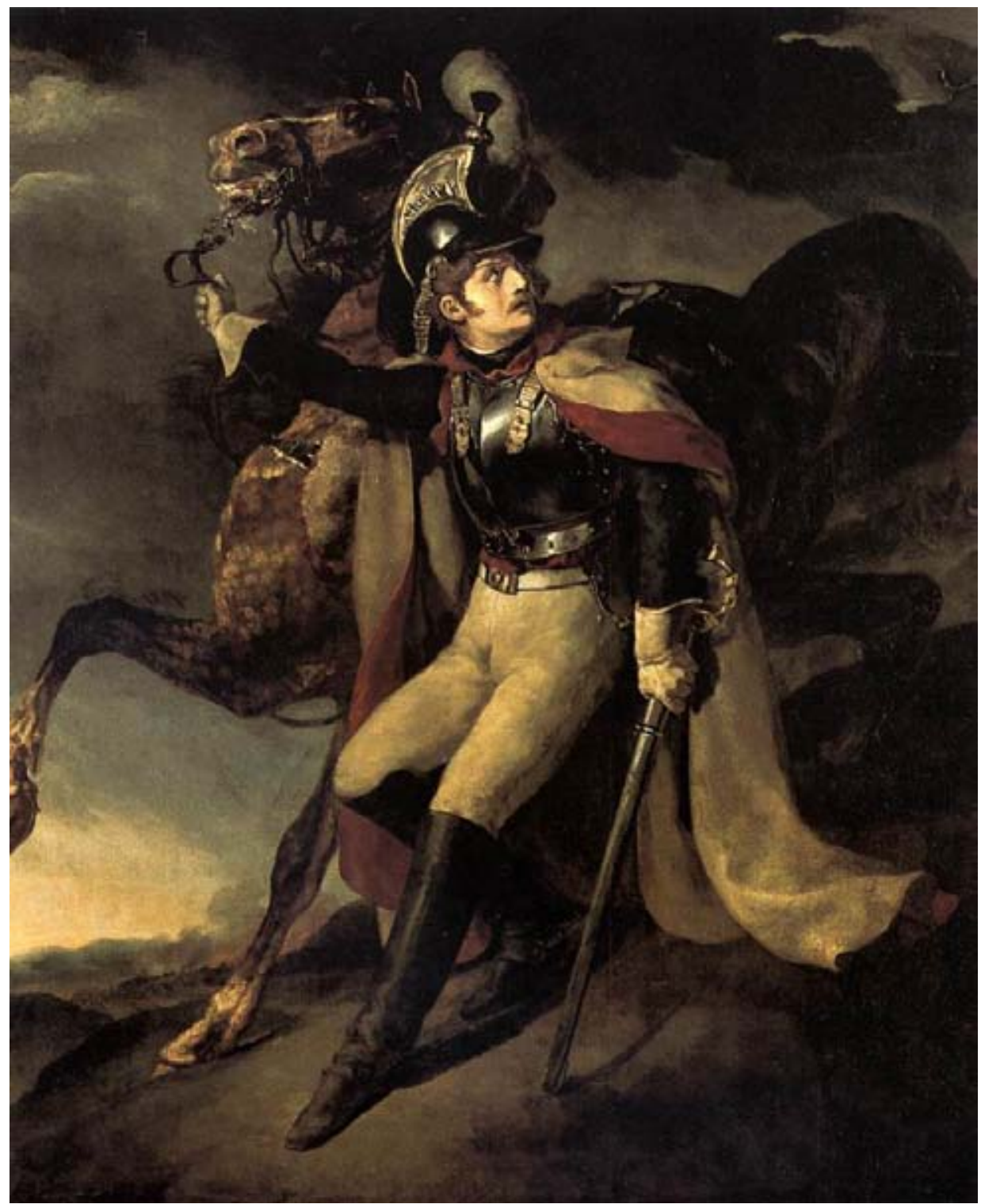

Plate 3: Théodore Géricault, Wounded Cuirassier Leaving the Field, 1814, oil on canvas, $358 \times 294 \mathrm{~cm}$.

Source: Musée du Louvre, Paris. Fair use is claimed for not-for-profit educational \& scholarship purposes. 


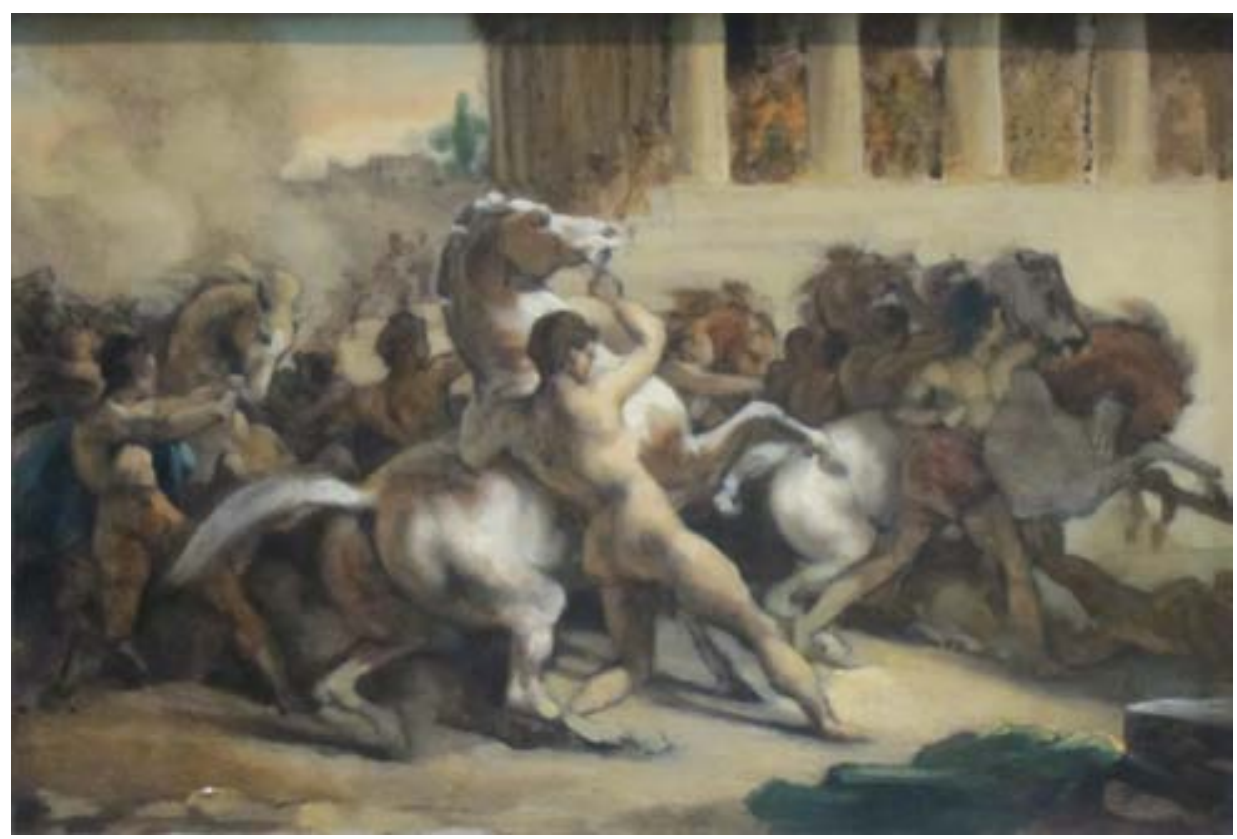

Plate 4: Théodore Géricault, The Race of the Riderless Horses, 1817, oil on paper laid on canvas, $20 \times 29 \mathrm{~cm}$.

Source: J. Paul Getty Museum, Los Angeles. Fair use is claimed for not-for-profit educational \& scholarship purposes.

These circumstances gave rise to the Géricault who would produce the quintessentially Romantic painting of the Raft of the Medusa: an irrepressible individuality that sought to portray lived experience rather than mythological irrelevance, a well-honed style that was formal yet eschewed dynamic restraint, the inner turmoil of his private woes and a disillusionment with the social and political upheaval of those years. His modern artistic vision that focused on the individual and expressed the complexity of the spirit of the times was nurtured and encouraged in this milieu, turning from the sketches of soldiers, sportsmen, and horses of his early youth to the contemporary, contentious, vital subject of the Raft, which he thought would grant him the attention and recognition necessary to 'astonish the world'.

The painting is an unresolved, existential plea for redemption that transcends the superficial, political veneer of its subject matter. Géricault's work presents a cascade of emotions that seem to ascend and descend between hope and despair, yet offer no true resolution, only a sense of vacant, emotionless ambivalence. Its composition is marked by two divergent, intersecting, pyramidal structuresone running from the deceased male on the left extreme of the foreground, to the tip of the cloth which the dark-skinned man is waving in the air; the other 
beginning from the faceless body of the deceased figure on the right extreme of the foreground, running to the top of the mast. The former seems to show a growing transition from despair to hope, contrasting the desolate stare of the father figure and the deceased bodies littering the wooden planks of the raft with the apparently desperate but hopeful gestures of the half-kneeling, halfsitting figures reaching out, upwards to a crescendo of salvific longing topped by the dark-skinned man, waving at the Argus, its mast faintly peeping out of the horizon. ${ }^{24}$

But there is no certainty of redemption, no satiation of the horrors of the fourteen days past. The figure in the centre, caught between the shoulders of the men with outstretched arms, almost seems to express a distressed torment, with his intense, yet emotionless expression, as if being repressed by the other two. Nature herself seems at odds with the frenzied hopes of the men on the raft, blowing gustily with an almost preternatural strength that causes the mast to billow leftwards. It seems almost cruel that instead of blowing directly away from the Argus, the wind is taking them on a course parallel with the Argus on its picture plane, prolonging their torturous uncertainty, the moment between assured jubilance and monumental dejection. The viewer cannot detach himself from the mental torment of the scene - the raft seems to extend outwards into the viewer's space, drawing and engaging him as a horrified participant onto this wooden contraption that does not seem far from coming apart. There is no true hope in this picture, only longing, whose outcome is rendered inconsequential by the irreparable sense of loss and decay that pervades the picture, epitomised by the figure of the father.

This figure, his left arm bulging with unnatural strength, is the only one who faces the viewer, perhaps assuming the role of the storyteller in conventional history painting. His well-developed musculature contrasts starkly with the limp torso of the son, whose red hair and lithe frame suggests an innocence that has been terminated with death. His absence of sentience and awkward posture makes his unclothed form border on the boundary between nudity and nakedness; the former connoting the rationalised acceptability and beauty of ideal form, the latter suggesting an intrusive, voyeuristic realism that borders on the vulgar. ${ }^{25}$ His open palms almost beckon the viewer to contemplate him not as a classical, archetypal nude, but signify an opening into a disturbed inner world.

The horror of this inner world stalks the painting with a clear reference to cannibalism - Salon visitors noted the similarity to portrayals of Count Ugolino,

24 Donald A. Rosenthal, 'Géricault's 'Raft of the Medusa' and Caravaggio', The Burlington Magazine, 120, no. 909 (Dec. 1978): 841.

25 Kenneth Clark, The Nude: A Study of Ideal Art (London: John Murray, 1960), 1-4. 
a notorious character in Romantic poetry and art, suspected of practising cannibalism on his sons and grandsons, such as in Henry Fuseli's Ugolino in the Tower (Plate 5). ${ }^{26}$

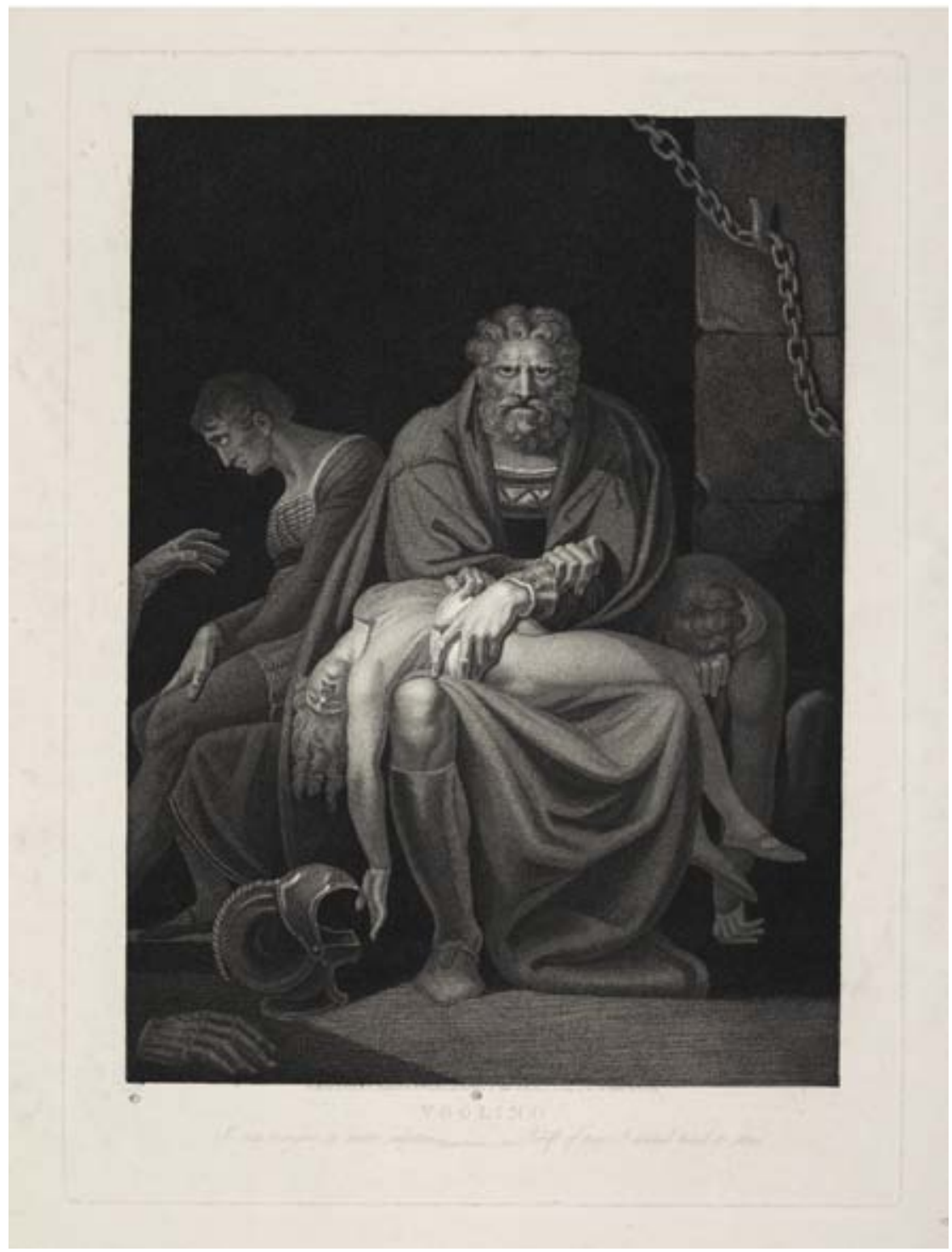

Plate 5: Henry Fuseli, Ugolini in the Tower, Engraving by Moses Haughton, 1809 (after Fuseli's painting of 1806), ink on paper, 61 x $44 \mathrm{~cm}$.

Source: The Trustees of the British Museum. Fair use is claimed for not-for-profit educational \& scholarship purposes.

26 Eitner, Géricault's Raft, 45. 
Géricault's earlier sketches reveal the genealogy of this father figure, originally a brutish cannibal, gradually transformed into the grieving father, his visage perhaps expressing not merely grief, but remorse (Plates 6-9). ${ }^{27}$ The bloodstained bandage on his left forearm hints at the position where his brutish ancestor had bit into his victim, heightening the repugnance of having eaten his flesh and blood, tantamount to eating himself (as the bandage demonstrates), the innocence of his son rendered meaningless by death-a death which our storyteller has partaken of; the vacancy of his expression a mark of the very lifelessness that overwhelms the painting. ${ }^{28}$

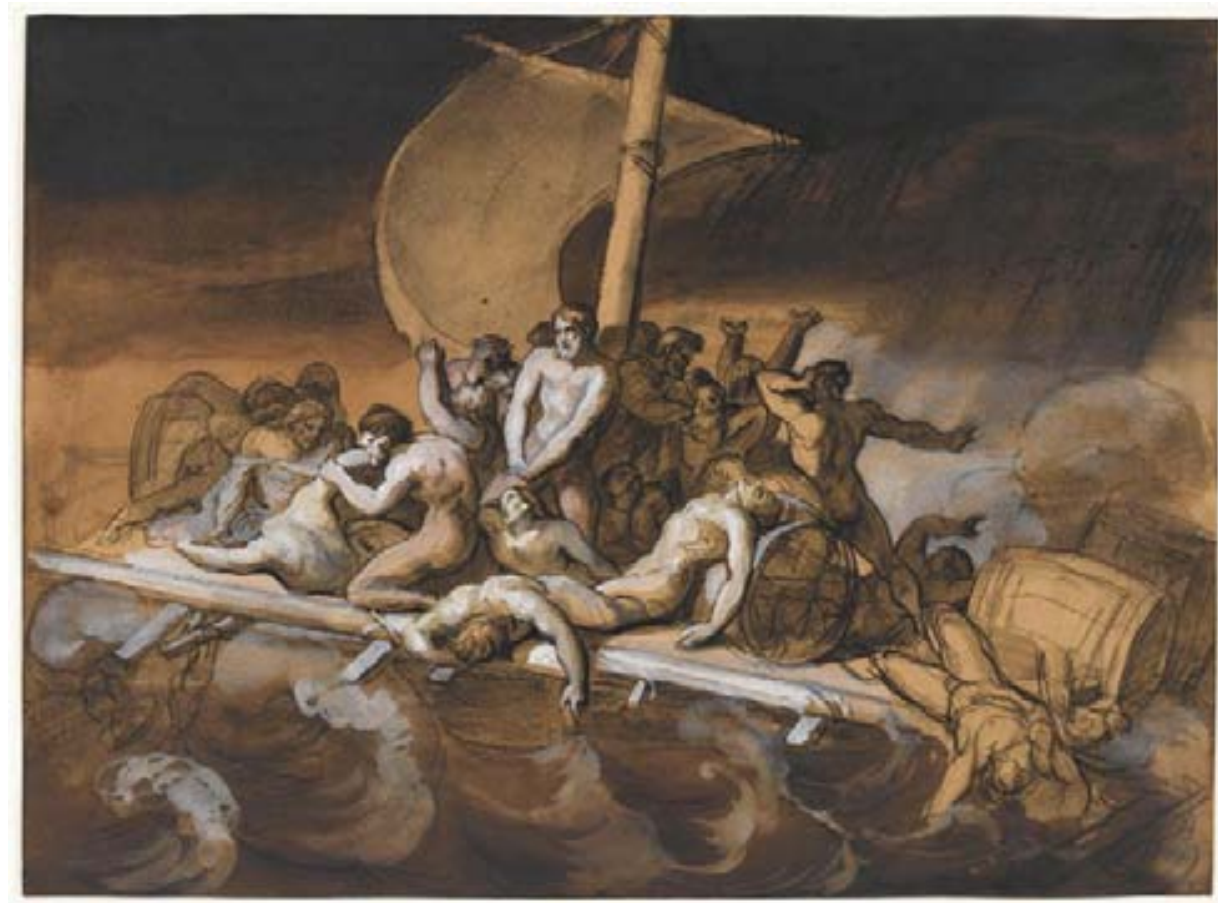

Plate 6: Théodore Géricault, Scene of Cannibalism, 1818-1819, crayon, ink wash, and gouache on paper, $28 \times 38 \mathrm{~cm}$.

Source: Musée du Louvre, Paris. Fair use is claimed for not-for-profit educational \& scholarship purposes.

27 Notice how the brutish cannibal in Plate 6 is manifested in the two characters of the brute (in body structure) and the grieving father (in posture) in Plate 7. This grieving father subsequently transits to his final form in Plate 9. Géricault has experimented with multiple incarnations of numerous forms and figures, involved in acts of mutiny and cannibalism, and this grieving father has emerged from his earlier cannibalistic existence; Darcy Grimaldo Grigsby, Extremities: Painting Empire in Post-Revolutionary France (New Haven: Yale University Press, 2002), 201-11.

28 Ibid., 215. 


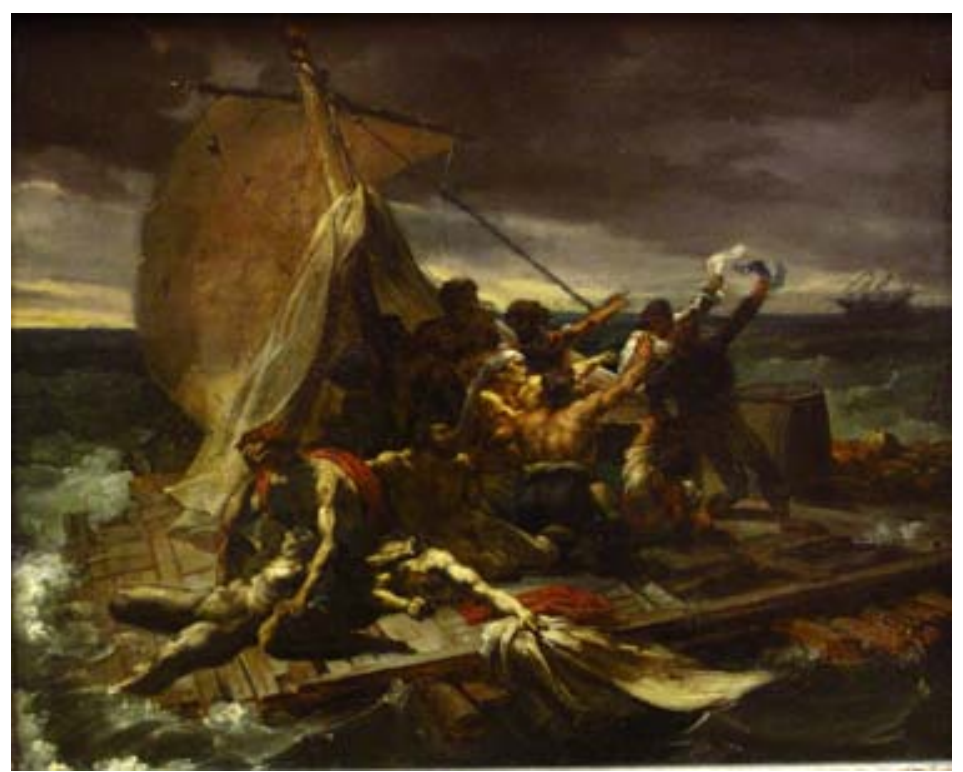

Plate 7: Théodore Géricault, Study for Raft of the Medusa, 1818-1819, oil on canvas, $38 \times 46 \mathrm{~cm}$.

Source: Musée du Louvre, Paris. Fair use is claimed for not-for-profit educational \& scholarship purposes.

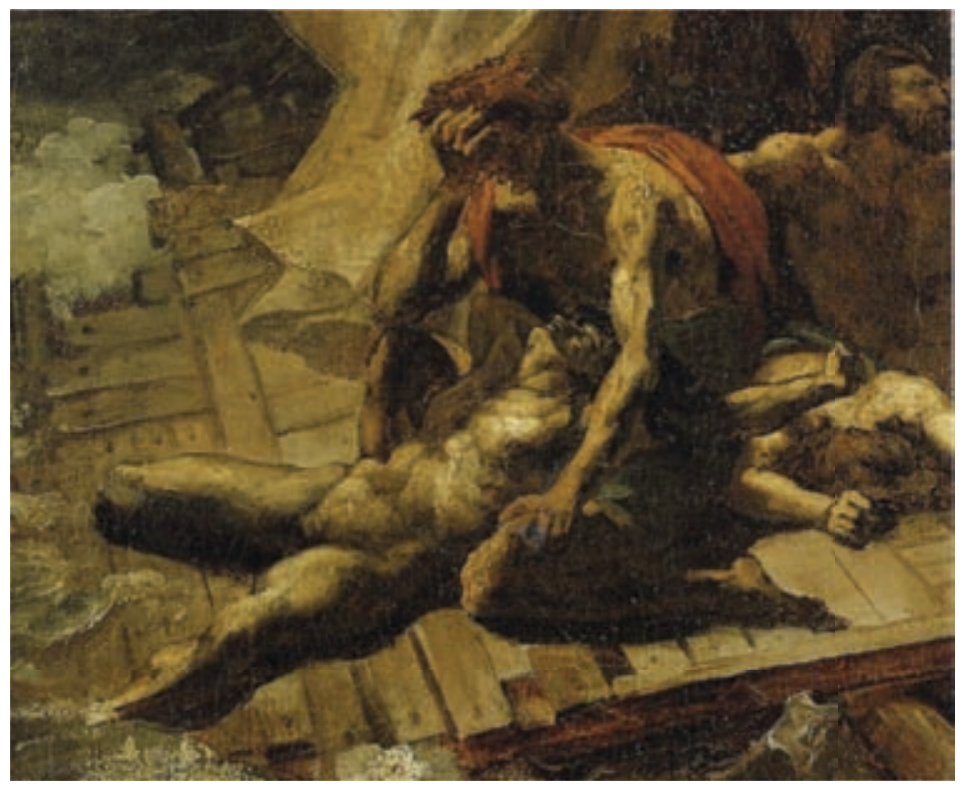

Plate 8: Théodore Géricault, detail from Study for Raft of the Medusa, 1818-1819, oil on canvas, 38 x $46 \mathrm{~cm}$.

Source: Musée du Louvre, Paris. Fair use is claimed for not-for-profit educational \& scholarship purposes. 


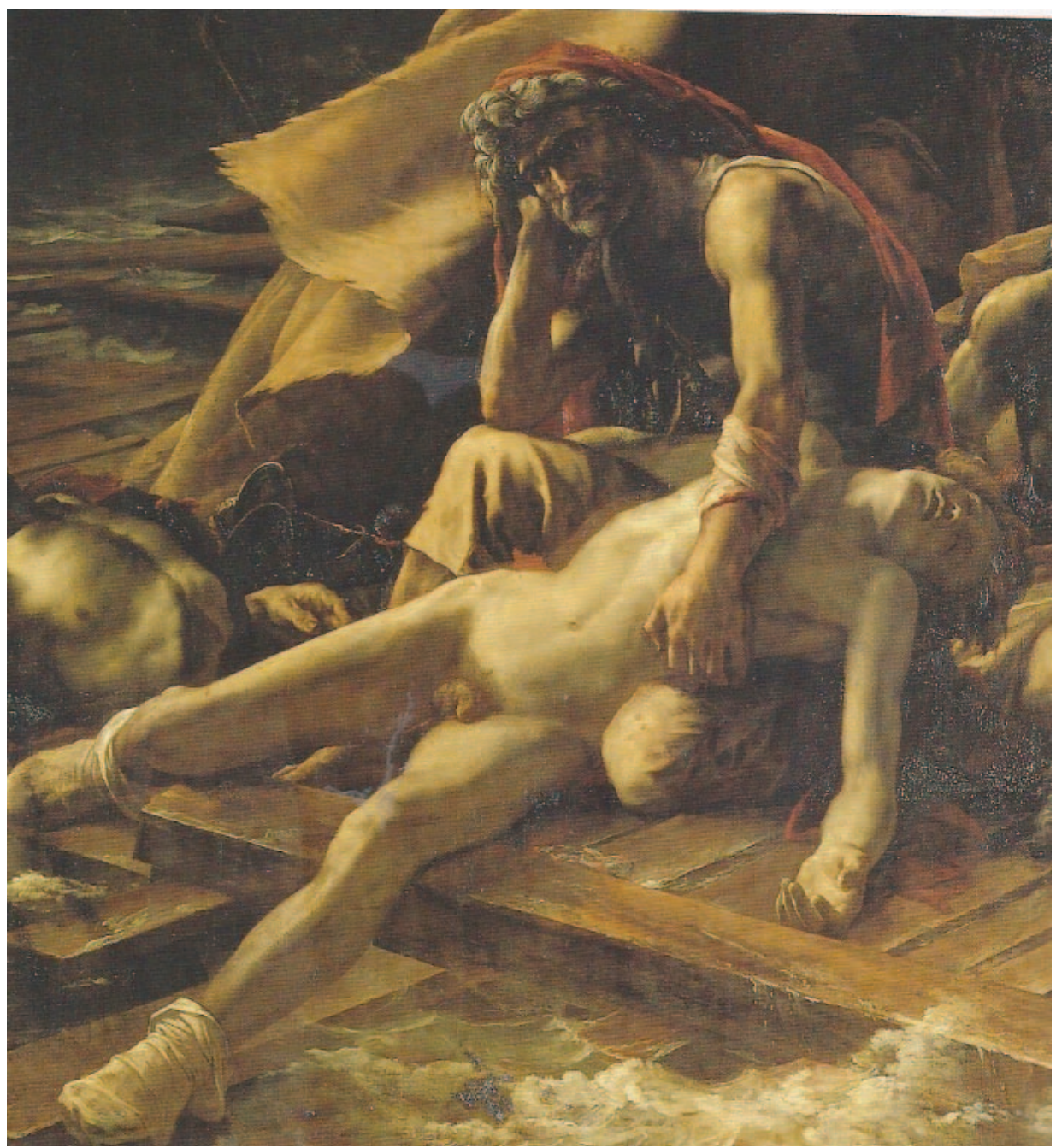

Plate 9: Théodore Géricault, detail from Raft of the Medusa, 1819, oil on canvas, $491 \times 716 \mathrm{~cm}$.

Source: Musée du Louvre, Paris. Fair use is claimed for not-for-profit educational \& scholarship purposes.

Death stalks the painting. Its horror accrues not from depicting scenes of mutiny, cannibalism and disordered chaos, but from the knowledge that this depicts the aftermath of a bloody narrative. These are characters forever marred by an unforgettable memory of the abominations that have occurred. The bloodstained axe head on the right, the headless body of the shrouded figure in the right foreground, the torso of the man in the extreme left foregroundhis bloated, putrefied hand and triangular gaping wound beneath his ribs and the absence of his lower body - together provide chilling hints of the original 
carnage. ${ }^{29}$ But death lives in life, too-not just in the father-son combination, as we have seen earlier, but in the mish-mash of bodies, torsos, limbs, dead and living, fused in the ensemble of movement characterised by the receding diagonal of the pyramid. This pyramid consists not of disparate characters, but a fused collective; its fluidity of motion accomplished by the outstretched arms and the gradually accelerating curve of the pyramid that achieves a speed that simultaneously dismembers and reassembles the collective.

In dismembering, this amalgamation of bodies becomes little more than a contortion of body parts - the flickering Caravaggesque chiaroscuro accentuating this cacophonous, tense fusion. Dead and live body parts intersperse with little distinction, such as the black man to the right of the painting, whose mouth lies close to the buttocks of the red-haired, youthful figure; the array of dead figures foregrounding the picture from left to right shroud the rest of the figures in the picture with a deathly pallor. ${ }^{30}$ This is but the meat of the cannibals: a "fricassée", in the words of one Salon critic. ${ }^{31}$ Dismembering results in reassembly. Irrelevance of difference between living and dead is mirrored by the indistinguishable characterisation - it is impossible to discern nationality, social status, and perhaps even race; the two figures closest to the right of the masthead, silhouetted in the darkness, could be Caucasian, African, or Asiatic, while the straight forehead and bearded visage, along with slightly upturned nose and prominent lips of the darkened figure in profile at the centre of the painting combines the Grecian and African models from a previous sketch (Plates 10-11); his position in the shadow engulfs him in a darkness that reveals nothing of his skin colour. ${ }^{32}$ The cannibalistic consummation of the collective has brought them into an egalitarian communion that transcends the hypocrisy of Savigny and Corréard's narrative. ${ }^{33}$ This communion affirms a utopian vision of universal fraternity, capped by the dark-skinned figure at the apex of the pyramid, but nevertheless a vision that is built on the unspeakable carnage of self-consumption. ${ }^{34}$

\footnotetext{
29 Ibid., 215-7.

30 Ibid., 215.

31 L'Observateur au Salon. Critique des tableaux en vaudeville (Paris, 1819), 10, quoted in Grimaldo Grigsby, Extremities, 218.

32 Grimaldo Grigsby, Extremities, 220-3.

33 While Savigny and Corréard's narrative ostensibly presents an egalitarian vision that condemns the extension of privilege to the upper classes in Restoration-era France, they too distance themselves from the soldiers, sailors, lower-class Frenchmen and Non-Caucasians on the raft and portray them as brutes whose behaviour, such as in the mutiny, proved their subclass status.

34 Fraternity (Fraternité) was sometimes included in mottos of the French Revolution referring to the harmonious brotherhood of human community.
} 
The ANU Undergraduate Research Journal

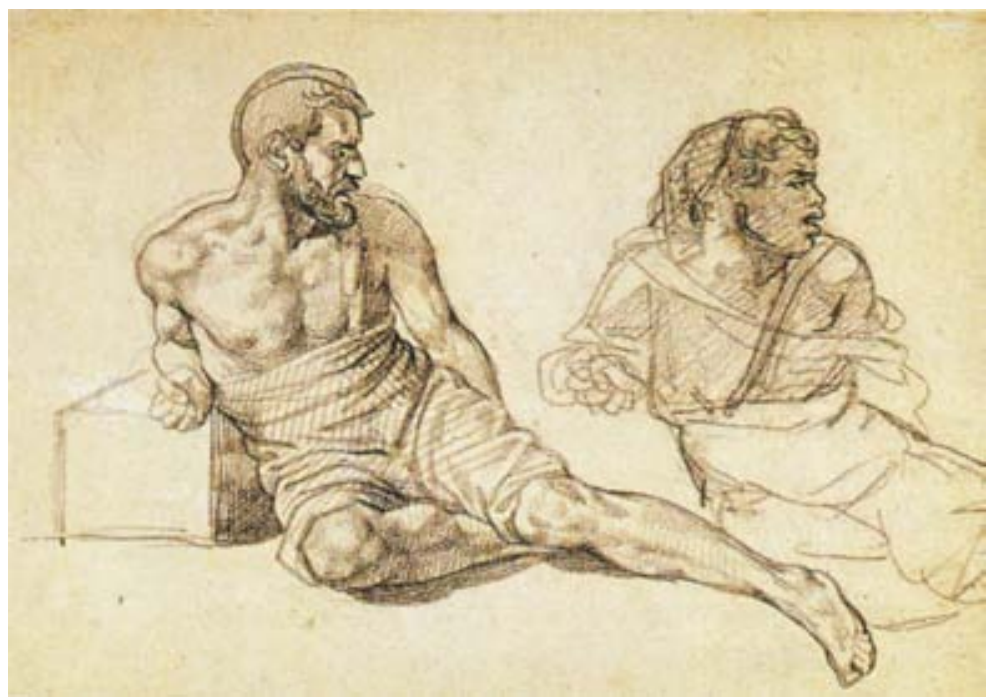

Plate 10: Théodore Géricault, Study for the seated Man on the "Father's" Right, 1818-1819, medium and dimensions unknown.

Source: Dubaut collection, Paris. Fair use is claimed for not-for-profit educational \& scholarship purposes.

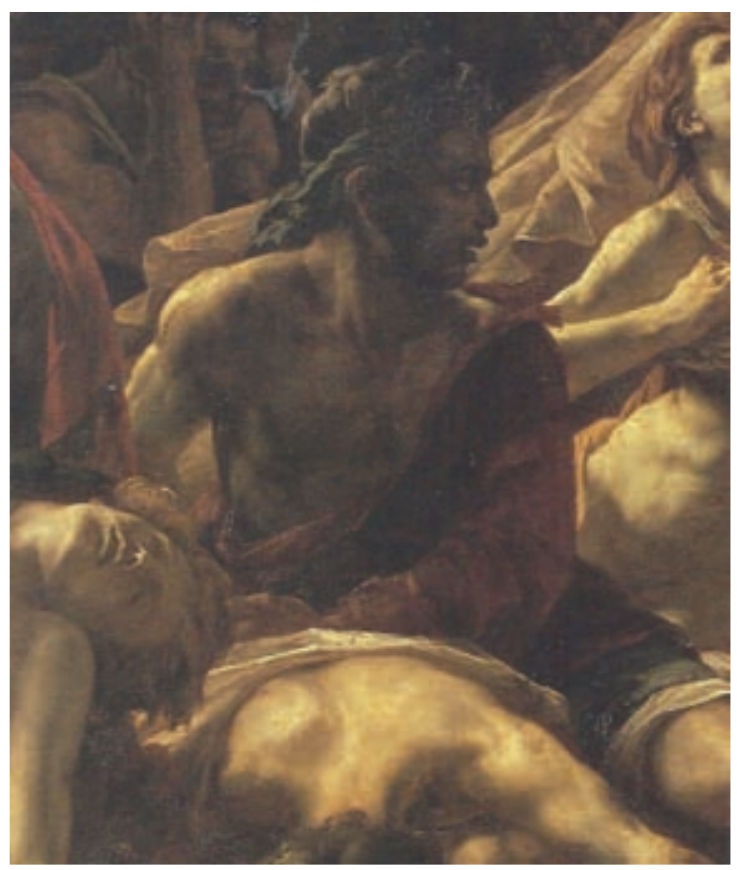

Plate 11: Théodore Géricault, detail from Raft of the Medusa, 1819, oil on canvas, $491 \times 716 \mathrm{~cm}$. 
Thus, this nightmarish inner world presents a hope that is perhaps unattainablethe egalitarian communion, representing Géricault's idealised world, loses its lustre as it is only conceivable in its perverted manifestation as a cannibalising fricassée that destroys itself from within. In Géricault's diseased world, the world is not only beyond redemption, but is also irreversibly and eternally disordered, alienated from the discourse of any narratives of redemption. Hence, this Scene of Shipwreck is irrevocably 'shipwrecked', turning the noun into its adjectival form; replacing the continuous diachrony of narrative with synchronous instantiation: a discordant, displaced eternity of a moment, forever lost, always reaching towards distant hope, all at sea. ${ }^{35}$ Géricault has departed the public and particular political spectacle of the Medusa for an inner landscape that universalises the painting with sublime emotions of lostness, a rumination on humanity that was not uncommon for his generation. The painting's only source of illumination emits from a point towards its right, suggesting a rising or setting sun, near a ship that might or might not come to their rescue. The expected warmth of the orange hues of sunlight is pale and drained of vitality, overshadowed by the greys of billowing clouds and greyish greens of thundering waves. Darkness haunts this picture - the projections of a mind fixated on death, despair and lostness.

Géricault's painting reflects the Romantic temperament as much as it paved the way for others to follow his synthesis of painterly realism and ideal forms. Its subordination of outer, idealised rationality to inner, subjective experience, fixated on the morbid, pushing towards the extremities of suffering and a loss of innocence, express not a message but a sense of the tragic, rooted not in the teleological redemption and resolution of Classicism, but in a persistent turbulence that channels the vast ambivalence of human experience. It is Romantic in emphasising an associative side that suggests a deeper reality encountered through the sublime; the open form, unidirectional movement in the painting that brooks no obvious consummation, and not the organised, narrativised nounal of the 'shipwreck'. The father figure as true story teller, plumbing the sombre realities of the human condition; not the figures of Savigny and Corréard, who gesture toward a false hope, speaking yet dissolving into the darkness, gagged as storytellers. ${ }^{36}$

The painting's contemporary reception by critics reveals less about Romanticism itself than the conservative forces of the Ancien Régime that it was rebelling against. There is little information about its public reception, though it must have captured the public's imagination with its unconventional style and prominent

35 Marie-Hélène Huet, 'The Face of Disaster', Yale French Studies, no. 111 (2007): 19.

36 Géricault has painted Savigny and Corréard as two figures standing beside the masthead; Vaughan,

Romanticism and Art, 11. 
place in the critics' reviews of the Salon. ${ }^{37}$ Critics were in general agreement that the painting reflected the work of a master, but bemoaned the uniform darkness of its colour. ${ }^{38}$ More interestingly, their criticism appeared to be divided by political affiliation, with the Liberals and Romantics proclaiming admiration for its subversive, beautifully executed horror and the Conservatives and classicists condemning its unheroic and morally bankruptcy with its repulsive depiction of death. ${ }^{39}$ The Liberal and Romantic critic of Le Constitutionnel wrote: "My heart trembled upon seeing the shipwreck of the Medusa ... I shudder while I admire." ${ }^{40}$ In contrast, the classicist critic of Le Courrier berated Géricault: "So, I am asking, twenty or so unfortunate men abandoned in a raft ... does this present a good opportunity for the brush to exert its talent?"41

The important observation is that both sides coloured their reviews of the painting through highly polarised lenses that overlooked its originality in the impact of its confronting and emotional pleas on the viewer, but instead employed a stock discourse that reflected the vast divisions in French politics of the time. Ironically, the critics' reviews validated and affirmed the Romantic artist's campaign as a valid response to the polemical artifice of the status quo. It demonstrated the painting's resilience in refusing to be drawn into contemporary politics, but in pioneering a style that would only flourish in the years after Géricault's death. Géricault died five years later in 1824, and his desire to 'astonish the world' would be fulfilled posthumously. In time, this painting would only grow in its potency as a Romantic symbol due to its association with the emerging myth of Géricault as the heroic, brooding Romantic artist. This legacy was firmly enshrined in the 1830s with Ary Scheffer's painting, The Death of Géricault, circulated in lithographs and which cemented his identity as a Romantic martyr (Plate 12). ${ }^{42}$

While Géricault's painting incorporates the ostentatious expressiveness of the Baroque, the monumentality of its figures also reflects the deep, inner sentiment of the Neoclassicist. These continuities flow unapologetically into his work, but serve to strengthen, rather than erode the robustness of the Romantic enterprise. Because the Romantic was premised on a response that meant a shift in paradigms - from traditional archetypes and an idealised notion of art to a more self-referential, darkly emotive and deeply personal orientation-Géricault was able to give these preceding styles a transformative interpretation that did not invent a new technique as much as it meant a more intuitive, expressive depiction of personality and emotion. The Raft of the Medusa demonstrates how

37 Eitner, Géricault's Raft, 57-8.

38 Athanassoglou-Kallmyer, Théodore Géricault, 138.

39 Ibid., 138, 144.

40 Le Constitutionnel, 26 August 1819, 195, quoted in Eitner, Géricault's Raft, 58.

41 Comte de Kératry, Le Courrier, quoted in Athanassoglou-Kallmyer, Théodore Géricault, 138.

42 Athanassoglou-Kallmyer, Théodore Géricault, 211. 
this nascent Romanticism is the complex product of a society and individual irrevocably shrouded in a time of crisis. The personal tragedies in his life were crises that were only made possible by the crisis faced by an emerging middleclass that strove to define itself and find its way out of the stagnant waters and "contrived reconciliation" of Restoration-era France. ${ }^{43}$

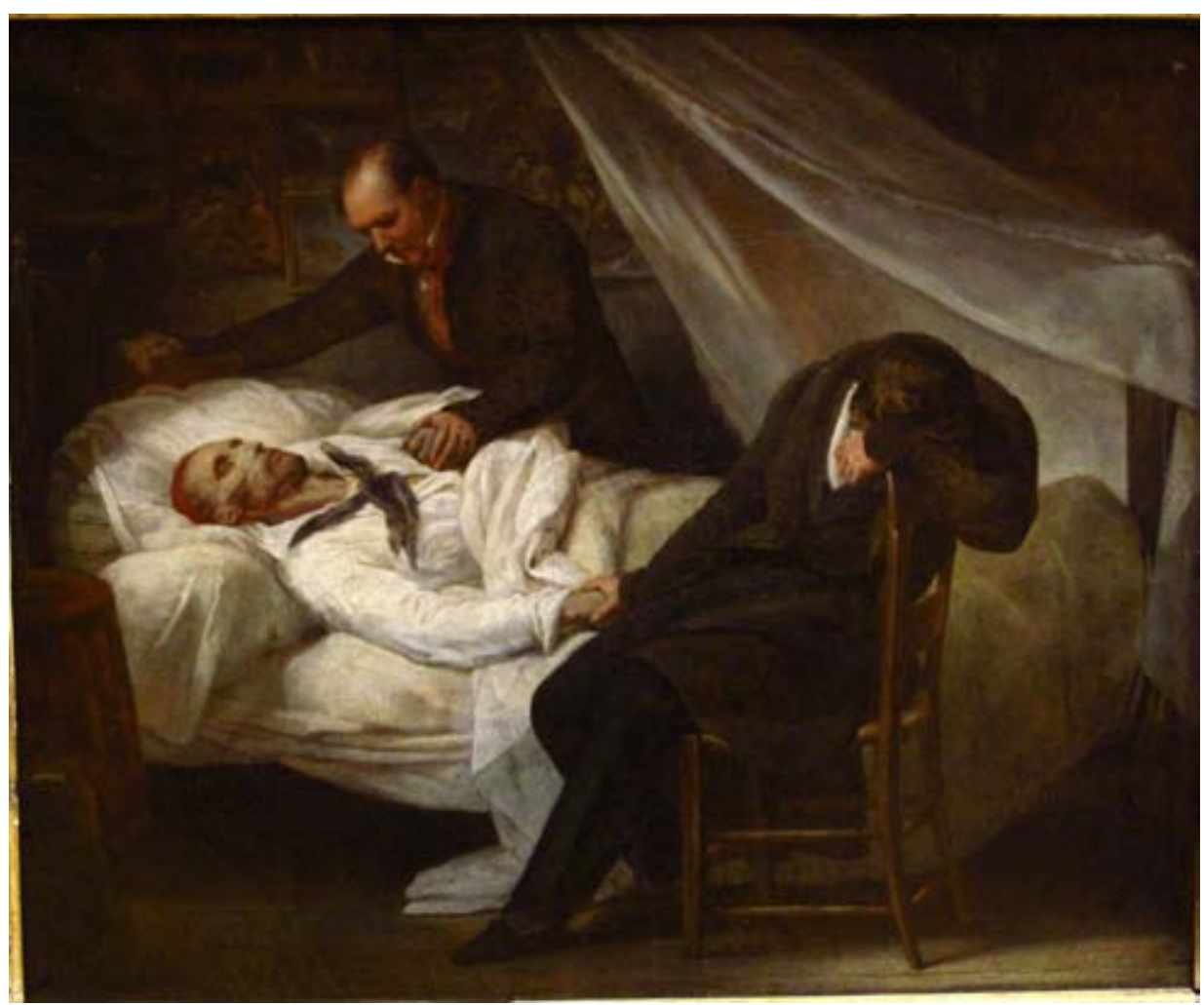

Plate 12: Ary Scheffer, The Death of Géricault, 1824, oil on canvas, $36 \times 46 \mathrm{~cm}$.

Source: Musée du Louvre, Paris. Fair use is claimed for not-for-profit educational \& scholarship purposes.

The sublime indeterminacies of a complex inner world would be but a brief respite for Géricault from the crises of his life, having witnessed the rise and fall of the Empire, the return of the Bourbons, the Hundred Days, the Restoration, forbidden love, declamatory ambition, and having endured his many temperamental passions. This retreat into a diseased and disordered inner world would further pull him towards his destruction, with a despondent statement he made following the lukewarm reception to his painting taking on prophetic 
The ANU Undergraduate Research Journal

tones: "What I want is the trial of misfortune." ${ }^{44}$ Carried along the waves of history, the emerging Romanticism of his era enabled Géricault to project in the Raft of the Medusa his vision of unheroic desolation and 'shipwrecked' abandon to the extremes of unmediated emotion, rocking him further out to sea as a talisman for others who would follow in his wake. All at sea.

\section{Bibliography}

Athanassoglou-Kallmyer, Nina. Théodore Géricault. London: Phaidon, 2010.

Brown, David Blayney. Romanticism. London: Phaidon, 2001.

Clark, Kenneth. The Nude: A Study of Ideal Art. London: John Murray, 1960.

Grimaldo Grigsby, Darcy. Extremities: Painting Empire in Post-Revolutionary France. New Haven: Yale University Press, 2002.

Eitner, Lorenz. Géricault's Raft of the Medusa. London: Phaidon, 1972.

Eitner, Lorenz and Nash, Steven A. Géricault: 1791-1824. San Francisco: The Fine Arts Museums of San Francisco, 1989.

Huet, Marie-Hélène. 'The Face of Disaster'. Yale French Studies, 111 (2007): 7-31.

Rosenthal, Donald A. 'Géricault's 'Raft of the Medusa' and Caravaggio'. The Burlington Magazine. 120, 909 (Dec. 1978): 836, 838-9, 841.

Trapp, Frank Anderson. 'Review of Géricault's Raft of the Medusa by Lorenz Eitner'. The Art Bulletin, 58 no. 1 (1976): 134-37.

Vaughan, William. Romanticism and Art. London: Thames and Hudson, 1994.

\section{Appendix A}

The Medusa debacle is narrated in Lorenz Eitner's publication Géricault's Raft of the Medusa:

On 2 July 1816, the government frigate La Méduse, flagship of a convoy carrying French soldiers and settlers to the colony of Senegal, struck bottom in shallow water close to the West African coast, south of Cap Blanc. The main cause of the mishap was the incompetence of the

44 Noted by Louis Batissier, Géricault's earliest biographer, quoted in P. Courthion, Géricault raconté par lui-même et par ses amis (Vésenaz-Geneva, 1947), 44, quoted in Eitner, Raft, 62. 
captain, Hugues Duroys de Chaumareys, a nobleman and returned émigré, who owed his appointment to ministerial protection rather than to his seamanship. Outrunning the smaller ships in his convoy, de Chaumareys had steered an erratic course through the shoals along the Mauretanian coast, with the result that, when he ran aground on the sands of Arguin, there were no ships near him to help re-float the Medusa. After two days of confused and ineffectual efforts, it became apparent that the ship must be abandoned. Only six lifeboats, of various sizes and different degrees of dilapidation, were on hand. They could take no more than about two hundred and fifty of the Medusa's four hundred passengers and crew. To accommodate the rest, a raft measuring about sixty-five feet in length and twenty-eight feet in width was built with the help of masts and beams crudely lashed together with ropes. On the morning of 5 July, the frigate, which had begun to break up, was abandoned with undisciplined haste. The captain and many of the senior officers, concerned only with their own safety, had the brutality of commandeering the more seaworthy boats, leaving it to the lower ranks and the soldiers to try their luck on the Raft. One hundred and fifty persons, including a woman, were herded onto the slippery beams, which immediately submerged under this weight...

An agreement had been made beforehand that all the boats should stay with the Raft and together tow it to the nearby shore. But in their haste to reach land, the men in the boats soon cut the cables which held them to the heavy Raft...

On the first night, several people lost their lives through having their lower bodies entangled in the interstices in the planks between the raft. On the next, many of the soldiers, who had been drinking, mutinied against their officers, leading to a battle where sixty-five men died. The next day, some of the survivors began to practise cannibalism, which eventually all engaged in by the fourth day. By the sixth day, twentyeight survivors remained, but only fifteen seemed healthy enough to hold out for longer. A council was held and the decision was made to throw these sick into the sea, to sustain the rest for another six days. These fifteen managed to suffer through another seven days, until 17 July, when the Argus, part of the Medusa's original convoy, rescued them. The Argus had disappeared after its initial sighting by the men on the raft, leading them to abandon hope. Two hours later, however, it returned. Five of the survivors died shortly after reaching land. The raft's voyage had lasted thirteen days and taken one hundred and forty lives. 